\title{
Effect of flyash and fertilizers on yield, nutrient uptake and soil nutrient status of groundnut (Arachis hypogea)
}

\section{A. SIREESHA AND P. PRASUNA RANI}

Received : 26.09.2014; Revised : 12.10.2014; Accepted : 30.10 .2014

\author{
MEMBERS OF RESEARCH FORUM: \\ Corresponding author : \\ A. SIREESHA, Andhra Pradesh Rice \\ Research Institute and Regional \\ Agricultural Research Station, \\ Maruteru, WEST GODAVARI (A.P.) \\ INDIA \\ Email: siridevaharshini@gmail.com
}

\section{Co-authors :}

P. PRASUNA RANI, Department of Soil Science and Agricultural Chemistry, Agricultural College, BAPATALA (A.P.) INDIA

\section{Summary}

A field experiment was conducted at College Farm, College of Agriculture, Bapatla during Rabi 2002-2003 to study the effect of flyash and fertilizer levels on yield and nutrient uptake of groundnut. The experiment was laid out in Randomized Block Design with Factorial Concept with four levels of flyash (0,5,10 and $\left.15 \mathrm{tha}^{-1}\right)$, four levels of fertilizers (70, 80, 90 and 100\% recommended dose of fertilizers) and a control without any fertilizers and flyash. The flyash collected from Vijayawada Thermal Power Station, Ibrahimpatnam is a potential source of plant nutrients. The pod and haulm yield and nutrient uptake significantly increased with flyash, fertilizers and their interaction. However, yield and nutrient uptake showed more response to the fertilizers than flyash. With increase in the levels of fertilizers, yield and nutrient uptake increased and the differences recorded between 70 per cent RDF and 80 per cent RDF were significant. However, at further levels increase showed decreasing trend and the difference was non-significant. Application of fly ash @ $10 \mathrm{tha}^{-1}$ increased the yield and nutrient uptake significantly over $0 \mathrm{tha}^{-1}$ and $5 \mathrm{t} \mathrm{ha}^{-1}$. However, with further increase in the levels of flyash $15 \mathrm{t} \mathrm{ha}^{-1}$, the increase was non-significant. The combined application of flyash @ $15 \mathrm{t} \mathrm{ha}^{-1}$ and fertilizer @ 100 per cent recommended dose was at par with flyash @ $10 \mathrm{t} \mathrm{ha}^{-1}$ and 80 per cent recommended dose of fertilizer gave significantly higher pod and haulm yield and nutrient uptake, suggesting 20 per cent saving of fertilizers. The soil was analyzed for micronutrient status using D.T.P.A. with atomic adsorption spectrophotometer. Soil extractable zinc, iron, manganese and copper content was significantly increased from 1.04 to $1.33,7.52$ to $10.11,12.84$ to 16.45 and 1.47 to 2.12 at harvest due to the application of flyash from 0 to $15 \mathrm{t} \mathrm{ha}^{-1}$. Application of fertilizers from 70 to 100 per cent of recommended dose significantly increased soil extractable zinc, iron, manganese and copper content increased from 1.13 to $1.25,8.66$ to $9.32,15.88$ to 17.06 and 1.71 to 1.89 at harvest. However, the interaction effect of both flyash and fertilizers was not significant. The increase in dehydrogenase enzyme activity was significant at lower doses of flyash application from 0 , to $10 \mathrm{t} \mathrm{ha}^{-1}$ further increase in enzyme activity due to the application of flyash was not significant. However, extensive studies with flyash on different crops are needed for further confirmation of the results.

Key words : Flyash, Fertilizers, Soil nutrient status, Dehydrogenase, Groundnut

How to cite this article : Sireesha, A. and Rani, P. Prasuna (2014). Effect of flyash and fertilizers on yield, nutrient uptake and soil nutrient status of groundnut (Arachis hypogea). Asian J. Soil Sci., 9(2): 226-233. 